\title{
The effect of variation in the calorie: protein ratio of the diet on nitrogen retention and body composition in the rat
}

\author{
By D. S. WAGLE, URMILA MARFATIA* AND A. SREENIVASAN \\ Central Food Technological Research Institute, Mysore, India
}

(Received 4 December 1961-Revised 5 February 1962)

It is generally recognized that nitrogen balance is influenced by the energy content of the diet. Many workers have noted the sparing action of energy-rich foods on protein utilization. Bosshardt \& Barnes (1946) showed that protein utilization by growing rats and mice increased with calorie intake when the animals were given isocaloric diets ad lib. Among other reports giving evidence of the protein-sparing action of calorie-rich foods are those of Swanson (I95I) and Marfatia \& Sreenivasan (1960) with rats, Rosenthal \& Allison (I95I) with dogs, and Leverton, Gram \& Chaloupka (195I) with young women. In a comprehensive review of literature on the subject, Munro ( $195^{\mathrm{I}}$ ) concluded that $\mathrm{N}$ retention is influenced foremost by the calorie intake of the animal.

Rosenthal \& Allison (I956) have suggested that there may be an optimum calorie intake for each level of dietary protein. That the food intake is determined by the calorie content of the diet has been demonstrated with chicks (Hill \& Dansky, 1950, 1954; Dansky \& Hill, I95 I Peterson, Grau \& Peek, 1954) and with dogs (Cowgill, 1928). Ontko, Wuthier \& Phillips (1957) have shown that optimum growth and optimum efficiency of food conversion are closely related to a rather sensitive balance between the amount of protein and the calorie content of the diet. Hegsted \& Haffenreffer (1949), working with rats, stated that the food intake of an animal is maintained by means yet unknown at a certain level above the normal basal metabolic requirements of the animal. Sibbald, Berg \& Bowland (1956), Sibbald, Bowland, Robblee \& Berg (1957 $a, b$ ) and Sibbald, Bowland, Berg \& Robblee (1957) have demonstrated with rats that an optimum calorie level exists for each $\mathrm{N}$ level of the diet and showed that the ratio of calories to $\mathrm{N}$ in the diet controls the percentage of $\mathrm{N}$ retained in the body. Yoshida, Harper \& Elvehjem (1957) have shown that the calorie to protein ratio is an important factor in growth and $\mathrm{N}$ utilization. It has also been shown that as the energy level of the diet increased the percentage of protein required for maximum growth also increased (Leong, Sunde, Bird \& Elvehjem, I955, 1959).

In addition, the ratio of available energy to protein has been shown to exert a considerable influence upon fat deposition in animals. As the ratio of energy to protein in the diet was increased, the calorie intake and deposition of carcass fat increased (Donaldson, Combs \& Romoser, 1956). Other studies with chicks(Hill \& Dansky, 1954; Peterson et al. 1954) have shown that as the non-metabolizable fibrous bulk increased

* Present address: Institute of Nutrition Sciences, Columbia University, 562 West 168th Street, New York 32, N.Y., U.S.A. 
the fat content of the carcass decreased. However, Sibbald, Bowland, Robblee \& Berg (1957 $a$ ) did not observe any major changes in the carcass composition relative to changes in the ratio of calories to protein in the diet. In view of the fact that the calorie:protein ratio profoundly influences growth and $\mathrm{N}$ retention, certain adjustments may be expected to occur in some tissues. In the work now described, the relationship between the calorie content of the diet and growth and $\mathrm{N}$ retention has been studied by ascertaining the effects on carcass, liver and plasma constituents of changes in the calorie:protein ratio in casein diets which either contained equal quantities of protein or were isocaloric, the calorie:protein ratio being modified by the inclusion of cellulose or by increasing the fat or protein content.

\section{EX PERIMENTAL}

Diets. The composition of the experimental diets is given in Table I. The calorie content of the diets was computed from the Atwater factors (Sherman, I952) for protein, carbohydrate and fat. Diets $I$ and 2 were equal in protein content but the calorie content of diet I was less owing to the inclusion of $30 \%$ cellulose. Diets I and 3 were isocaloric but diet 3 provided more protein. The protein content of diets 3 and 4 was increased to compensate for the increased excretion of metabolic nitrogen

Table I. Percentage composition of the diets

\begin{tabular}{|c|c|c|c|c|c|c|}
\hline Constituent & Diet $\mathbf{I}$ & Diet 2 & Diet 3 & Diet 4 & Diet 5 & Diet 6 \\
\hline Vitamin-free casein* & $15^{\circ} 0$ & I $5 \cdot 0$ & $21 \cdot 5$ & $2 I \cdot 5$ & 15.0 & $15 \cdot 0$ \\
\hline Maize starch & $46 \cdot 0$ & $76 \cdot 0$ & $39 \cdot 5$ & $35 \cdot 5$ & $42 \cdot 0$ & $72 \cdot 0$ \\
\hline Cellulose† & $30 \cdot 0$ & - & $30 \cdot 0$ & 30.0 & $30 \cdot 0$ & - \\
\hline Sesame oilf & 4.0 & $4 \cdot 0$ & $4^{\circ} \cdot 0$ & $8 \cdot 0$ & $8 \cdot 0$ & $8 \cdot 0$ \\
\hline Salt mixture§ & $4 \cdot 0$ & $4 \circ 0$ & 4.0 & $4 \cdot 0$ & $4 \cdot 0$ & $4^{\circ} \mathrm{O}$ \\
\hline Vitaminized sucrose 9 & $1 \cdot 0$ & $1 \cdot 0$ & $x \cdot 0$ & $x \cdot 0$ & $1 \cdot 0$ & I.O \\
\hline Calories (kcal/100 g) & 284 & 404 & 284 & 304 & 304 & 424 \\
\hline $\begin{array}{l}\text { Ratio, calories (kcal): } \\
\text { protein }(\mathrm{g})\end{array}$ & $19^{\circ} 0$ & $27 \cdot 0$ & $13 \cdot 2$ & I4. I & $20 \cdot 3$ & $28 \cdot 3$ \\
\hline
\end{tabular}

* Prepared by repeated hot alcohol extraction (twenty-five to thirty times) of crude casein (Polson's Dairy Farm Ltd, Anand, India) in a Soxhlet-type extractor.

$\uparrow$ Acid-washed powdered filter-paper.

$I$ Provided $(\mathrm{mg} / \mathrm{I} 00 \mathrm{~g}$ diet): vitamin A acetate $0.3 \mathrm{I}$, vitamin D (calciferol) 0.0045 and $\alpha$-tocopherol $5 \cdot 0$.

$\S$ United States Pharmacopoeia XIV (1950).

9 Contained $(\mathrm{mg} / \mathrm{g})$ : thiamine hydrochloride 0.3 , riboflavin 0.4 , pyridoxine hydrochloride 0.3 , calcium pantothenate $I \cdot 0$, nicotinic acid $2 \cdot 0$, folic acid $0 \cdot 1$, cyanocobalamin $0 \cdot 015, p$-aminobenzoic acid I0.0, biotin 0.05 , inositol 20 , choline chloride 20 and menaphthone 0.5 .

that might result from addition of cellulose (Meyer, 1956). Diets 3 and 4 were again equal in protein content but the calorie content of diet 4 was slightly greater owing to the higher percentage of fat in it $(8 \%$ against $4 \%)$. Diets 5 and 4 were similar respectively to diets $I$ and 3 except that a greater percentage of calories was derived from fat. Again, diets 5 and 6 were similar respectively to diets $I$ and 2, with a greater contribution of calories from fat. These changes in dietary constituents brought about variations in the calorie:protein ratios which were pronounced when cellulose was added to or withdrawn from the diet. 
Animals and management. Male weanling rats of the Wistar strain were used. They were housed individually in raised mesh-bottom cages and had free access to food and water.

Procedure. The rats were given the experimental diets for 4 weeks and weight gain and food consumption were recorded during this period. $N$ retention was measured during a 4-day period in the last week. The animals were placed individually in round metabolism cages for collection of urine and faeces. The $\mathrm{N}$ content of the excreta pooled for the 4-day period was determined by the Kjeldahl method.

At the end of the experimental period, the animals were killed under ether anaesthesia and blood and liver samples were collected for analysis. Blood was withdrawn from the portal vein, immediately heparinized and centrifuged in the cold $\left(4^{\circ}\right)$ to obtain the plasma. Livers were perfused with ice-cold $0.25 \mathrm{M}$-sucrose solution and quickly removed, blotted and made into $10 \%$ homogenates with $0.25 \mathrm{M}$-sucrose in a Potter-Elvehjem homogenizer. The homogenate was separated into nuclear and mitochondrial fractions by the differential centrifugation procedure of Schneider \& Hogeboom (1950) in a PR-2 model refrigerated centrifuge (International Equipment Co., Boston, Mass., USA) and the microsomal fraction by the procedure of Palade $\&$ Siekevitz (1955) in a Spinco model L-preparative centrifuge. The purity of nuclear and mitochondrial fractions was assessed by determining deoxyribonucleic acid content and succinic dehydrogenase activity respectively. Total $\mathrm{N}$ in liver homogenate and its fractions (Umbreit, Burris \& Stauffer, I946), mitochondrial succinoxidase (Schneider \& Potter, I943), xanthine oxidase in the soluble fraction (Dhungat \& Sreenivasan, I954) and plasma total proteins and the quantities of electrophoretically separated protein fractions (Mulgaonkar \& Sreenivasan, 1959) were determined by the methods of the authors cited. Total lipids were determined as described by Wagle, Mitbander \& Sreenivasan (I962). Phospholipids were determined in the total lipids as obtained above by first digesting with $30 \%(\mathrm{w} / \mathrm{v})$ sulphuric acid and then estimating phosphorus by the method of Taussky \& Shorr (1953). The phospholipid content was calculated by using 25 as the factor for conversion of phosphorus into phospholipids. Cholesterol was determined by the method of Schoenheimer \& Sperry (1934), ubiquinone by the method of Aiyar, Sulebele, Rege \& Sreenivasan (1959) and $\alpha$-tocopherol by that of Nair \& Magar (1956). Total and non-collagen $\mathrm{N}$ in muscle were determined by the method of Mendes \& Waterlow (1958).

\section{RESULTS AND DISCUSSION}

The results for weight gain, food intake, protein efficiency ratio (PER) and $\mathrm{N}$ retention are summarized in Table 2. Inclusion of cellulose in the diets at the expense of starch and fat retarded the rate of weight gain; this effect was offset in part by increasing the content of protein or calories or both. Food intake was also less on the diets with extra cellulose. The inclusion of $30 \%$ cellulose in the diet apparently prevented the animals from consuming sufficient food to satisfy their requirements, which limited their weight gain. Other workers (Peterson et al. 1954; Sibbald et al. I956) have noted that the food intake of weanling rats is significantly influenced by 
the energy content of the diet and that, within physiological limits, the animals eat to satisfy their energy requirement, but a low protein intake limits the need for food energy by limiting growth. The PERs were higher for the groups given the diets without cellulose; however, they were higher for the groups given cellulose with more fat but not with more protein in the diet. It would appear, therefore, that when the calorie content of the diet is reduced by the inclusion of cellulose, the protein component may be used to meet energy needs. Hence improvement in PER may be expected from the ingestion of more calories when fat is added to the diet or cellulose removed from it.

Table 2. Effects of variations in the calorie:protein ratio of the diet on weight gain, protein efficiency ratio and nitrogen balance

\begin{tabular}{|c|c|c|c|c|c|c|}
\hline \multirow[b]{2}{*}{$\begin{array}{c}\text { Group* } \\
\text { no. }\end{array}$} & \multicolumn{5}{|c|}{ (Mean values for groups of six rats) } & \multirow[b]{2}{*}{$\begin{array}{l}\mathrm{N}_{\text {retained }} \uparrow \\
(\mathrm{mg} / \text { day })\end{array}$} \\
\hline & $\begin{array}{l}\text { Weight gain } \\
\text { in } 4 \text { weeks } \\
(\mathrm{g})\end{array}$ & $\begin{array}{c}\text { Food } \\
\text { intake } \\
\text { (g/day) }\end{array}$ & PER & $\begin{array}{l}\mathrm{N} \text { intake } \\
(\mathrm{mg} / \text { day })\end{array}$ & $\begin{array}{c}\text { Calorie } \\
\text { intake } \dagger \\
\text { (kcal/day) }\end{array}$ & \\
\hline I & $75^{\cdot 2}$ & $8 \cdot 4$ & $2 \cdot 13$ & 203 & $25^{\circ} \circ$ & 97 \\
\hline 2 & $121 \cdot 5$ & 10.2 & $2 \cdot 84$ & 242 & $42 \cdot 4$ & 162 \\
\hline 3 & 85.6 & $8 \cdot 5$ & $I \cdot 67$ & 284 & 24.4 & 126 \\
\hline 4 & $95 \cdot 7$ & $9 \cdot 5$ & $I .67$ & $32 \mathrm{I}$ & 29.5 & 149 \\
\hline 5 & 110.8 & $9 \cdot 6$ & 2.75 & 228 & 30.1 & 137 \\
\hline 6 & 133.3 & 10.5 & 3.02 & 235 & 45.4 & 170 \\
\hline sef & 4.0 & 0.8 & - & 16 & $3 \cdot 1$ & 8 \\
\hline
\end{tabular}

The adverse effects of cellulose on $\mathrm{N}$ retention were offset in part by increased $\mathrm{N}$ intake when the protein level of the diet was raised or when the calorie intake was higher on a high-fat diet. A similar reduction in $\mathrm{N}$ retention with addition of fibre to the diet (Meyer, 1956; Sibbald, Bowland, Robblee \& Berg, $1957 a$ ) and improvement in $\mathrm{N}$ balance with increased calorie intake (Swanson, 195 I; Calloway \& Spector, I955; Sibbald et al. 1956) or increased protein intake (Munro, 195 I) have been reported. It has also been shown (Allison, Anderson \& Seeley, 1946) that a reduction of energy intake to $25 \%$ of the requirement impairs the ability of dogs to respond to an increase in dietary protein. In other words, energy intake is a factor limiting utilization of protein added to the diet. Under normal nutritional conditions, $\mathrm{N}$ balance is improved by an increase in either energy or protein intake.

Values for carcass composition (Table 3 ) show that the two low-protein diets of higher calorie value (diets 2 and 6) led to substantially higher body $\mathrm{N}$ contents than did the other two low-protein diets (diets $\mathrm{I}$ and 5 ). Similar increments in body $\mathrm{N}$ content were produced by raising the protein content of the $\operatorname{diet}$ (diets 3 and 4 ), even though the ratio of calorie intake to protein intake was thereby reduced. Addition of cellulose caused a slight increase in the water content of the carcass. It can also be seen that the fat content of the body increased as the calorie intake was raised by removing the cellulose or by increasing the fat content of the diet. However, the fat content was less with the high-protein diets. As the dietary ratio of energy to protein 
decreased, the fat content of the body decreased. In the chick, the fat content of the carcass has been shown to decrease as the level of indigestible material in the diet increases (Hill \& Dansky, 1954; Peterson et al. 1954). A similar tendency for the water content of the carcass to increase and the fat content to decrease with the addition of cellulose to the diet has been noted (Sibbald, Bowland, Robblee \& Berg, I957a).

Table 3. Carcass composition of rats receiving diets with different calorie:protein ratios

(Mean values for groups of six rats)

$\begin{array}{cccc}\begin{array}{c}\text { Group* } \\ \text { no. }\end{array} & \begin{array}{c}\text { Water } \\ (\%)\end{array} & \begin{array}{c}\text { Nitrogen } \\ (\%)\end{array} & \begin{array}{c}\text { Lipids } \\ (\%)\end{array} \\ \text { I } & 69.3 & 3.11 & 6.5 \\ 2 & 66.1 & 3.35 & 9.2 \\ 3 & 70.5 & 3.21 & 6.2 \\ 4 & 71.8 & 3.34 & 6.0 \\ 5 & 69.6 & 3.07 & 7 \cdot 3 \\ 6 & 65 \cdot 2 & 3.27 & 10.5 \\ \text { SE* }^{*} & 0.6 & 0.04 & 0.6\end{array}$

Table 4. Distribution of nitrogen in liver and muscle of rats receiving diets with different calorie:protein ratios

\begin{tabular}{|c|c|c|c|c|c|c|c|c|}
\hline \multirow[b]{3}{*}{$\begin{array}{c}\text { Group* } \\
\text { no. }\end{array}$} & \multirow{3}{*}{$\begin{array}{l}\text { Liver } \\
\text { weight/ } \\
\text { roog } \\
\text { body- } \\
\text { weight } \\
\text { (g) }\end{array}$} & \multicolumn{5}{|c|}{ (Mean values for groups of six rats) } & \multirow{2}{*}{\multicolumn{2}{|c|}{ Muscle nitrogen }} \\
\hline & & \multicolumn{5}{|c|}{ Liver nitrogen } & & \\
\hline & & $\begin{array}{c}\text { Total } \\
(\mathrm{mg} / \mathrm{g})\end{array}$ & $\begin{array}{l}\text { Nuclear } \\
(\mathrm{mg} / \mathrm{g})\end{array}$ & $\begin{array}{l}\text { Mito- } \\
\text { chondrial } \\
(\mathrm{mg} / \mathrm{g})\end{array}$ & $\begin{array}{c}\text { Micro- } \\
\text { somal } \\
(\mathrm{mg} / \mathrm{g})\end{array}$ & $\begin{array}{l}\text { Soluble } \\
\text { (mg/g) }\end{array}$ & $\begin{array}{r}\text { Total } \\
(\mathrm{mg} / \mathrm{g})\end{array}$ & $\begin{array}{l}\text { Non- } \\
\text { collagen } \\
(\mathrm{mg} / \mathrm{g})\end{array}$ \\
\hline I & $3 \cdot 25$ & $30 \cdot 0$ & $6 \cdot 5$ & $5 \cdot 9$ & $4 \cdot 4$ & $13 \cdot 8$ & $26 \cdot 3$ & $2 x \cdot 1$ \\
\hline 2 & 3.52 & $36 \cdot 1$ & $7 \cdot 3$ & $6 \cdot 6$ & $5 \cdot 3$ & $17 \cdot 3$ & $28 \cdot 7$ & $23 \cdot 8$ \\
\hline 3 & $3 \cdot 31$ & $34 \cdot 2$ & $7 \cdot 3$ & $6 \cdot 7$ & $4 \cdot 8$ & $15 \cdot 2$ & $27 \cdot 0$ & $24 \cdot 2$ \\
\hline 4 & $3 \cdot 44$ & $33^{\circ} 0$ & $6 \cdot 9$ & $6 \cdot 3$ & $4 \cdot 6$ & $15 \cdot 3$ & $28 \cdot 3$ & $25 \cdot 5$ \\
\hline 5 & $3 \cdot 35$ & $32 \cdot 7$ & $6 \cdot 9$ & $6 \cdot 4$ & $4 \cdot 8$ & 15.0 & $26 \cdot 1$ & 244 \\
\hline 6 & $3 \cdot 65$ & $34 \cdot 5$ & $7 \cdot 2$ & $6 \cdot 3$ & $5 \cdot 2$ & I6. 5 & 27.8 & 25.7 \\
\hline $\mathrm{SE}^{*}$ & - & $I \cdot 2$ & 0.2 & 0.2 & 0.2 & 0.8 & $\mathrm{I} \cdot 3$ & I. 4 \\
\hline
\end{tabular}

The findings on $\mathrm{N}$ distribution in the liver and in muscle are summarized in Table 4. Inclusion of cellulose in the diet resulted in a reduction in the $\mathrm{N}$ content of liver and muscle. However, the reduction was partly corrected by increasing the dietary protein content or by replacing cellulose with a calorie source. These changes were more pronounced in the soluble proteins than in the other fractions. The variations in the $\mathrm{N}$ content of muscle were small, but the non-collagen $\mathrm{N}$, constituting the cytoplasmic proteins and reflecting metabolic processes (Mendes \& Waterlow, 1958), showed generally no change except with the lower-protein diet with cellulose. Thus liver $\mathrm{N}$ content not only depends on dietary protein content, but is also influenced by calorie intake. Such an influence on liver cytoplasm can be inferred from the studies 
of Campbell \& Kosterlitz (I948) and Munro (I95I) who have observed the effects of altering the energy intake from carbohydrate or fat.

Changes in succinoxidase and xanthine oxidase activities were studied as these enzymes are typical respectively of a mitochondrial protein concerned in oxidative metabolism and a soluble labile protein. Contents of ubiquinone and $\alpha$-tocopherol were also ascertained as they are essential lipid components. The results are summarized

Table 5. Succinoxidase and xanthine oxidase activities and $\alpha$-tocopherol and ubiquinone contents of livers of rats receiving diets with different calorie:protein ratios

(Mean values for groups of six rats on fresh-weight basis)

\begin{tabular}{|c|c|c|c|c|}
\hline $\begin{array}{c}\text { Group* } \\
\text { no. }\end{array}$ & $\begin{array}{c}\text { Succin- } \\
\text { oxidase } \\
\left(\mu \mathrm{I} \mathrm{O}_{2} / \mathrm{h} \mathrm{g}\right)\end{array}$ & $\begin{array}{c}\text { Xanthine } \\
\text { oxidase } \\
\left(\mu \mathrm{l} \mathrm{O}_{2} / \mathrm{h} \mathrm{g}\right)\end{array}$ & $\begin{array}{c}\alpha \text {-Tocopherol } \\
(\mu \mathrm{g} / \mathrm{g})\end{array}$ & $\begin{array}{l}\text { Ubiquinone } \\
\quad(\mu \mathrm{g} / \mathrm{g})\end{array}$ \\
\hline I & $5^{880}$ & $35 \mathrm{I}$ & $8 \cdot 8$ & 97 \\
\hline 2 & 7560 & 462 & I I.O & × 29 \\
\hline 3 & 6200 & 406 & $9 \cdot 8$ & I I I \\
\hline 4 & 6225 & 426 & $9 \cdot 5$ & 117 \\
\hline 5 & 6575 & $43^{\circ}$ & 10.3 & I 36 \\
\hline 6 & 7425 & 480 & 10.9 & I 53 \\
\hline $\mathrm{SE}^{*}$ & 87 & 20 & 0.7 & 10 \\
\hline
\end{tabular}

Table 6. Contents of total lipids, phospholipids and cholesterol in liver and plasma of rats receiving diets with different calorie:protein ratios

(Mean values for groups of six rats)

\begin{tabular}{|c|c|c|c|c|c|c|c|c|}
\hline \multirow[b]{3}{*}{$\begin{array}{c}\text { Group* } \\
\text { no. }\end{array}$} & \multicolumn{4}{|c|}{ Liver ( $\mathrm{mg} / \mathrm{g}$ fresh tissue) } & \multicolumn{4}{|c|}{ Plasma (mg/roo ml) } \\
\hline & \multirow[b]{2}{*}{$\begin{array}{l}\text { Total } \\
\text { lipids }\end{array}$} & \multirow[b]{2}{*}{$\begin{array}{l}\text { Phospho- } \\
\text { lipids }\end{array}$} & \multicolumn{2}{|c|}{ Cholesterol } & \multirow[b]{2}{*}{$\begin{array}{l}\text { Total } \\
\text { lipids }\end{array}$} & \multirow[b]{2}{*}{$\begin{array}{l}\text { Phospho- } \\
\text { lipids }\end{array}$} & \multicolumn{2}{|c|}{ Cholesterol } \\
\hline & & & Total & Free & & & Total & Free \\
\hline I & $72 \cdot 4$ & $18 \cdot 7$ & $2 \cdot 75$ & $r \cdot 45$ & 202 & 121 & 48 & I 3 \\
\hline 2 & $85 \cdot 2$ & $24 \cdot 5$ & 3.01 & $1 \cdot 58$ & 245 & 144 & 55 & I 5 \\
\hline 3 & $60 \cdot 5$ & $17 \cdot 5$ & $2 \cdot 92$ & $I \cdot 6 I$ & 195 & 125 & 42 & I 3 \\
\hline 4 & $69 \cdot 3$ & $18 \cdot 8$ & $3 \cdot 0 \mathrm{r}$ & $\mathrm{I} \cdot 5 \mathrm{I}$ & 206 & I 3 I & 47 & 14 \\
\hline 5 & $80 \cdot 6$ & $22 \cdot 6$ & $2 \cdot 9 \mathrm{I}$ & $1 \cdot 65$ & 209 & I 39 & 52 & I 5 \\
\hline 6 & $9 \pi \cdot 2$ & $26 \cdot 2$ & $3 \cdot 10$ & $1 \cdot 66$ & $25^{8}$ & I 64 & $6 I$ & I 5 \\
\hline $\mathrm{SE}^{*}$ & $\mathrm{I} \cdot 8$ & $\mathrm{I} \cdot 3$ & 0.06 & 0.04 & 10 & 7 & $\mathbf{I} \cdot \mathbf{2}$ & 0.6 \\
\hline
\end{tabular}

in Table 5. The activities of both succinoxidase and xanthine oxidase were reduced in animals given the diets with the lower calorie:protein ratios caused by addition of cellulose. It is well recognized that inadequacy of dietary protein is immediately reflected in the labile protein reserves (Allison, 1955). Xanthine oxidase, being an extremely labile protein, is known to reflect the protein quality of the diet. The relationship of the succinoxidase content of tissue with the $\alpha$-tocopherol content (Tappel $\&$ Zalkin, I959; Edwin \& Green, 1960) and the dependence of ubiquinone levels on $\alpha$-tocopherol content (Edwin, Diplock, Bunyan \& Green, 196r) would explain the changes observed in the succinoxidase, $\alpha$-tocopherol and ubiquinone contents of the 
livers. The parallelism observed between ubiquinone level and succinoxidase activity is in conformity with the reported participation of ubiquinone in electron transport in general and succinoxidase in particular (Aiyar et al. 1959; Aiyar \& Sreenivasan, I96I ; Green \& Lester, I959; Hatefi, Lester, Crane \& Widmer, 1959).

Table 6 gives the lipid composition of both liver and plasma in terms of total lipids, phospholipids and cholesterol. The increased total lipid content of the livers of the rats given the high-fat diet was reduced to some extent by the inclusion of cellulose in the diet, more so with the higher-protein diet. The phospholipids were affected similarly, but there was little change in the cholesterol content. It appears therefore that the extra calories ingested from the diets without cellulose could have been deposited as lipid material. This suggestion is supported by the finding of increased carcass lipid content in the animals given the diet without cellulose. The changes in plasma lipids were similar to those in liver. Their content was highest in the groups not given cellulose and higher with the high-fat and lower-protein diet. Increases in content of total cholesterol and phospholipid were more or less parallel. The content of free cholesterol did not appear to change significantly. It is apparent therefore that, as more lipid material is synthesized in the liver as a result of higher calorie ingestion, the plasma levels of lipids are also increased to transport the extra lipid to be deposited in the fat depots of the body.

Table 7. Quantities $(\mathrm{g} / \mathrm{1} 00 \mathrm{ml})$ of total protein and the electrophoretically separated protein fractions of plasma of rats receiving diets with different calorie:protein ratios

(Mean values for groups of six rats)

$\begin{array}{cc}\begin{array}{c}\text { Group* } \\ \text { no. }\end{array} & \begin{array}{c}\text { Total } \\ \text { proteins }\end{array} \\ \text { I } & 6.12 \\ 2 & 7.35 \\ 3 & 6.81 \\ 4 & 6.75 \\ 5 & 6.60 \\ 6 & 7.05 \\ \mathrm{SE}^{*} & 0.16\end{array}$

\begin{tabular}{|c|c|c|c|c|}
\hline \multirow[b]{2}{*}{ Albumin } & \multicolumn{4}{|c|}{ Globulin } \\
\hline & $\alpha_{1}$ & $\alpha_{2}$ & $\beta$ & $\gamma$ \\
\hline $\begin{array}{l}2 \cdot 22 \\
2 \cdot 8 \mathrm{I}\end{array}$ & $\begin{array}{l}I \cdot 2 I \\
I \cdot 60\end{array}$ & $\begin{array}{l}0.62 \\
0.82\end{array}$ & $\begin{array}{l}0.95 \\
1.12\end{array}$ & $\begin{array}{l}0.98 \\
1.06\end{array}$ \\
\hline $2 \cdot 44$ & $I \cdot 48$ & 0.71 & I.OI & 0.99 \\
\hline $2 \cdot 58$ & $I \cdot 52$ & 0.70 & 0.98 & $1 \cdot 02$ \\
\hline $\begin{array}{l}2 \cdot 32 \\
2.66\end{array}$ & $\begin{array}{l}I \cdot 32 \\
I \cdot 58\end{array}$ & $\begin{array}{l}0.72 \\
0.81\end{array}$ & $\begin{array}{l}I \cdot 10 \\
1 \cdot 25\end{array}$ & $\begin{array}{l}1.05 \\
1.09\end{array}$ \\
\hline 0.09 & 0.06 & 0.05 & 0.06 & 0.06 \\
\hline
\end{tabular}

The electrophoretic pattern of plasma proteins (Table 7) shows that the concentration of total proteins was reduced as cellulose was introduced into the diet; however, raising the dietary protein resulted in increasing their concentration. This reduction in total proteins was reflected more in albumin than in $\alpha_{1}$-globulin and $\alpha_{2}$-globulin. The changes in $\beta$-globulin and $\gamma$-globulin were not pronounced. The quantities of albumin, $\alpha_{1}$-globulin and $\alpha_{2}$-globulin have been shown to depend on dietary intake of protein (Allison, 1955; Mulgaonkar \& Sreenivasan, 1959). Thus, whereas the dietary protein content determines the quantities of the more labile plasma proteins, the calorie content of the diet has a significant part, more so when a diluent like cellulose is present in the diet. 


\section{SUMMARY}

I. Weanling rats were fed for 4 weeks on diets containing casein and varied with respect to protein and calorie components. The calorie:protein ratios were changed by changing the levels of protein, carbohydrate and fat and by the inclusion of cellulose up to $30 \%$. Weight gain, nitrogen retention and carcass composition were determined. The livers were analysed for $N$ content of the cell fractions, activities of succinoxidase and xanthine oxidase and contents of $\alpha$-tocopherol and ubiquinone. Lipid composition in terms of total lipids, phospholipids and cholesterol was determined in both liver and plasma. The plasma proteins were electrophoretically fractionated and determined quantitatively.

2. Addition of cellulose to the diet retarded rate of weight gain and lowered food intake; however, increase in protein or calorie content had a favourable effect.

3. Increase in the protein or calorie content of the diet increased $\mathrm{N}$ retention.

4. Carcass analysis showed that as the calorie:protein ratio of the diet was raised, there was increased deposition of lipid in the body.

5. The $\mathrm{N}$ content of muscle and liver was also reduced by the addition of cellulose to the diet, the changes being more marked in the soluble proteins.

6. The activities of succinoxidase and xanthine oxidase in liver were reduced as the calorie:protein ratio of the diet was lowered by addition of cellulose.

7. The changes in $\alpha$-tocopherol and ubiquinone content of the liver paralleled those in succinoxidase activity.

8. As the ratio of calories to protein in the diet was increased, the content of total lipids as well as phospholipids increased in liver and plasma, but changes in cholesterol content were only slight.

9. The electrophoretic pattern of plasma protein fractions showed that addition of cellulose to the diet caused a reduction in total proteins with concomitant reductions in the concentrations of albumin, $\alpha_{1}$-globulin and $\alpha_{2}$-globulin. The levels increased when the protein content of the diet was raised or when cellulose was replaced by a calorie source.

Our thanks are due to the Williams-Waterman Fund, Research Corporation, New York, for a grant-in-aid.

\section{REFERENCES}

Aiyar, A. S. \& Sreenivasan, A. (196r). Nature, Lond., I90, 344.

Aiyar, A. S., Sulebele, G. A., Rege, D. V. \& Sreenivasan, A. (1959). Nature, Lond., 184, 1867.

Allison, J. B. (1955). Physiol. Rev. 35, 664.

Allison, J. B., Anderson, J. A. \& Seeley, R. D. (1946). Ann. N.Y. Acad. Sci. 47, 245.

Bosshardt, D. K. \& Barnes, R. H. (1946). Fed. Proc. 5, 228.

Calloway, D. H. \& Spector, H. (1955). F. Nutr. 56, 533 .

Campbell, R. M. \& Kosterlitz, H. W. (1948). F. Physiol. 107, 383.

Cowgill, G. R. (1928). Amer. F. Physiol. 85, 45.

Dansky, L. M. \& Hill, F. W. (1951). Poult. Sci. 30, 9 1о.

Dhungat, S. B. \& Sreenivasan, A. (1954). F. biol. Chem. 208, 845 .

Donaldson, W. E., Combs, G. F. \& Romoser, G. L. (1956). Poult. Sci. 35, I I 00.

Edwin, E. E., Diplock, A. T., Bunyan, J. \& Green, J. (196I). Biochem. Э. 79, 9r.

Edwin, E. E. \& Green, J. (1960). Arch. Biochem. Biophys. 87, 337. 
Green, D. E. \& Lester, R. L. (1959). Fed. Proc. 18, 987.

Hatefi, Y., Lester, R. L., Crane, F. L. \& Widmer, C. (I959). Biochim. biophys. Acta, 3I, 490.

Hegsted, D. M. \& Haffenreffer, V. K. (1949). Amer. F. Physiol. 157, 141.

Hill, F. W. \& Dansky, L. M. (1950). Poult. Sci. 29, 763.

Hill, F. W. \& Dansky, L. M. (1954). Poult, Sci. 33, II2.

Leong, K. C., Sunde, M. L., Bird, H. R. \& Elvehjem, C. A. (1955). Poult. Sci. 34, I 206.

Leong, K. C., Sunde, M. L., Bird, H. R. \& Elvehjem, C. A. (1959). Poult. Sci. 38, I 267.

Leverton, R. M., Gram, M. R. \& Chaloupka, M. (195I). F. Nutr. 44, 537.

Marfatia, U. \& Sreenivasan, A. (1960). F. Nutr. 7o, I 56 .

Mendes, C. B. \& Waterlow, J. C. (1958). Brit. $\mathcal{F}$. Nutr. 12, 74.

Meyer, J. H. (1956). F. Nutr. 58, 407.

Mulgaonkar, A. G. \& Sreenivasan, A. (I959). Proc. Indian Acad. Sci. 49, 408.

Muriro, H. N. (r95r). Physiol. Rev. 3r, 449.

Nair, P. P. \& Magar, N. G. (1956). F. biol. Chem. 220, I 57.

Ontko, J. A., Wuthier, R. E. \& Phillips, P. H. (1957). F. Nutr. 62, I63.

Palade, G. E. \& Siekevitz, P. (1955). Fed. Proc. 14, 262.

Peterson, D. W., Grau, C. R. \& Peek, N. F. (1954). F. Nutr. 52, 24 I.

Rosenthal, H. L. \& Allison, J. B. (I95I). F. Nutr. 44, 423.

Rosenthal, H. L. \& Allison, J. B. (1956). F. agric. Fd Chem. 4, 792.

Schneider, W. C. \& Hogeboom, G. H. (1950). F. biol. Chem. 183, 123.

Schneider, W. C. \& Potter, V. R. (1943). F. biol. Chem. 149, 217.

Schoenheimer, R. \& Sperry, W. M. (1934). F. biol. Chem. 106, 745.

Sherman, H. C. (1952). Chemistry of Food and Nutrition, 8th ed., p. 135. New York: The Macmillan Co. Sibbald, I. R., Berg, R. T. \& Bowland, J. P. (1956). F. Nutr. 59, 385.

Sibbald, I. R., Bowland, J. P., Berg, R. T. \& Robblee, A. R. (1957). F. Nutr. 62, 17 I.

Sibbald, I. R., Bowland, J. P., Robblee, A. R. \& Berg, R. T. (I957a). F. Nutr. 6r, 7 r.

Sibbald, I. R., Bowland, J. P., Robblee, A. R. \& Berg, R. T. (1957b). F. Nutr. 62, I85.

Swanson, P. P. (195 I). Fed. Proc. 10, 660.

Tappel, A. L. \& Zalkin, H. (r959). Arch. Biochem. Biophys. 80, 333.

Taussky, H. H. \& Shorr, E. (1953). F. biol. Chem. 202, 675.

Umbreit, W. W., Burris, R. H. \& Stauffer, J. F. (1946). Manometric Techniques and Related Methods for the Study of Tissue Metabolism, p. 103. Minneapolis, Min.: Burgess Publishing Co.

Wagle, D. S., Mitbander, V. B. \& Sreenivasan, A. (1962). F. Nutr. 76, 199.

Yoshida, A., Harper, A. E. \& Elvehjem, C. A. (1957). F. Nutr. 63, 555. 